\title{
Influence of Entrepreneurship Education on Students Attaining Business Development Awareness and Skills Acquisition in Nigeria
}

\author{
${ }^{1}$ Ugochukwu Chinonso Okolie, ${ }^{2}$ Elisha N. Elom (Ph.D), ${ }^{3}$ Afam Ituma (Ph.D), \\ ${ }^{4}$ Patrick Nnamdi Opara (Ph.D), ${ }^{5}$ Nworie Job Ukwa, ${ }^{6}$ Emmanuel Ejike Inyiagu \\ (Ph.D), and ${ }^{7}$ Joseph Ndem (Ph.D) \\ ${ }^{1,2,4,6 \& 7}$ Department of Technology and Vocational Education, Ebonyi State University, Abakaliki, Nigeria. \\ 2,5 Federal University Ndufu-Alike, Ikwo, Nigeria.
}

\begin{abstract}
The purpose of this study was to verify entrepreneurship education influence on Nigerian higher education institutions students in attaining business development awareness and skills acquisition. It also sorts to comprehend the extent business development awareness and skill acquisition have been attained by students of Nigerian higher education institutions as a result of entrepreneurship education. An evaluation design was adopted for the study which covered five higher education institutions in Imo and Ebonyi states. Two research questions and two null hypotheses were formulated to guide the study. A purposive sample technique was used to select 280 students for the study. Five hundred and sixty (560) students were used for the study and the main instrument used for data collection was objective realization test constructed by the researchers. The instrument was subjected to face and content validation as well as item analysis to determine difficulty level and discrimination index. The extent of attainment of business development awareness and skill acquisition was based on a criterion referenced test determine through a trial testing of the instrument on a group of 30 respondents. K-R 20 approach was used to determine a reliability coefficient of 0.97 which was judged highly consistent hypotheses were tested at 0.05 level of significant. Mean and standard deviation were used to answer the research questions. The results among others revealed that business development awareness and skills acquisition have been attained by many Nigerian higher education institutions students to a little extent as a result of entrepreneurship education. Based on the findings of the study, recommendations were made. Keywords: Entrepreneurship, Entrepreneurship Education, Skills Acquisition, Business Development, Business Awareness
\end{abstract}

\section{Introduction}

Education is the process of learning and training; it is an instrument for change and development. Education is the springboard to socio-economic growth and development of every nation. It prepares an individual to live in a dynamic or constantly changing society and contribute to such changes and constantly advance the survival, growth and development of the society (Nwaham, 2010). Education generally, is a social process that helps to maintain a dynamic society since the creation of human beings; it has been variously defined by educational experts-like the ten blind me of Hindustan describing the elephant, these experts focus their definitions on various aspects of education (Nwuzo, Okolie and Igwe, 2013). Observing this, Onyeachu (2006) noted that it is through education that the cultural heritages are transferred from generation to generation.

Education is the most powerful instrument in the world because no nation has ever attained fame or a particular height in terms of development without education as its bedrock, which is engendered by sound educational ideals. Thus Onwumere (2006) saw education as the springboard for socio-political, economic and cultural development that enhances the production of skilled manpower for national development. There are informal and formal system of education, the formal structure of education should be encouraged. Moreover the acquisitions of certificate alone without a corresponding creative and mental power have no serious bearing on the purpose of education (Uloko, 2010). Education as parameter, registers the tempo of change and as well the rapid transformation of any society (Akpojena, 2010). There is high increase in the demand for education at all levels in Nigeria that promotes skills acquisition for survival in the society; by the same token, it is through such education that the acquired skills can be transferred into business development, which will in turn contribute to economic growth and development in Nigeria. And such education is entrepreneurship education.

What were are mainly concerned with in this study is to agree on the extent at which higher education students attain business development awareness and skills acquisition through entrepreneurship education in Nigeria. We first drew round a succinct task of education as the mainly heady mechanism for imparting the entrepreneurial development skills in the higher education students. Subsequently, we defined skills acquisition, 
entrepreneurship education, and business development; we also reviewed literatures that made them germane to the study matter. Statement of the problem of the study as well as the research questions and research methodology were presented, which lead to the findings of the study. We advocate new directions for research predominantly life skills-based entrepreneurial development studies. Our study is novel in finding out the extent at which business development awareness and skills acquisition has been attained by higher education students in Nigeria. So it suggested that Entrepreneurship education with skills and competencies acquired can help Nigeria maintain its material civilization by enabling the individual to keep pace with the rapidly changing business, industrial and technological growth and development. In other words, the future of entrepreneurship education must be seen as an instrument for transforming Nigeria's resources into completed goods and services that will endorse higher standard of living (Olateju, (2013); Okolie, (2010).

\section{Skills Acquisition}

The word skill is one of the relative terms with various definitions; depending on what one feels it is. Okorie (2000) defined skill as expertness, practical ability, dexterity and tact; and organized sequence of actions, proficiency executed and usually displayed in flexible but systematic temporal pattern. He further viewed skill as manual dexterity through repetitive performance of an operation. Skill therefore, is a well established habit of doing something. It involves the attainment of performance capability. To acquire or posses a skill is to demonstrate the habit of acting, thinking and behaving until a process becomes natural to the individual through reverberation or practice.

The acquired skills and competencies can manifest in the life of the students to assist them improve on higher standard of life in the community (Odu, 2010). Skill is the ability to do something expertly and well (Uloko, 2010). It is an organized sequence of actions, proficiently executed and usually displayed in flexible but systematic temporal patterning, (Okorie 2000). Skill can be looked at as the ability to acquire an expert knowledge in the formation of a process and it is usually expected that the acquisition takes the process of learning. Hull (1982), noted that Skill is a manual dexterity through repetitive performance of an operation. This implies mastery, but the acquisition of mastery or skill requires training to be competent towards the accomplishment of a task; requires focused consistency on the intended technique in achieving the skill or attaining mastery relevant to the given task.

One is said to be skillful, if a process is carried out perfectly and with efficiency and result-oriented. In the words of Odu (2010), to posses skill is to exhibit the habit of acting, thinking and behaving in a specific activity in such a way that the process becomes natural to the individual through repetition or practice. Skill development is very imperative in harnessing a nation's natural resources; it helps in developing intrinsic potentials in individuals and it is a significant function of educational institutions principally tertiary institutions. (Okeke 2005). According to Guthrie (1952), skill is the ability to bring about some end results with maximum certainty through the rhythmic performance of an act which is acquired through training. According to Osuala (1995) skill comprises two components, the knowledge components and activity component.

Ezeji and Okorie (1988) identified three major categories of skills in any training programme; these are technical skills, human skill and conceptual skill. Technical skill according to them, calls for understanding and proficiency in a specific activity, particularly one involving methods, processes, procedures or techniques. Human skill refers to the ability of an individual to work effectively in a group situation to foster co-operative effort within the group of which he is the team leader. Conceptual ability involves ability to recognize the interdependence of the various functions of an organization.

The National Policy on Education (NPE) (2004) recommends the use of technical skill for empowering or preparing youths for the world of work in the Nigerian schools. There is no doubt that sufficient skill is acquired through the study of entrepreneurship education as it gives learners opportunities to develop the knowledge and attitudes needed to take constructive actions; to create and become entrepreneurs. It is commonly assumed that the attainment of the obligatory skills is a means of escalating the industrious power of a nation hence, the Nigerian society should be familiar with the fact that every citizen should be outfitted to contribute efficiently to the welfare of the country. Moreover, it has been observed that the highest possible welfare is achieved only when each individual produces to the boundary of his capacity. Skill training therefore, is the procedure for designing stimulators to develop the skills of different constituent of job or task of a particular trade.

Skills acquisition is high-flying in many trades such as: woodwork, metalwork, building construction, tailoring and dress making, agriculture, spinning, weaving, dyeing, pot-making, shoe-making and repairing, plumbing, electrical installation, block laying and concreting, painting and decorating, carpentry and joinery, furniture making, motor vehicle mechanics work, electronics radio and television servicing, sign-writing, printing etc in Nigeria. It varies in nature and complexity according to the trade involved (Okolie, 2010). Individuals who opt for entrepreneurship education should, among other things, posses qualities such as that would enable them succeed in it. Therefore, the acquisition of appropriate skill in entrepreneurship education is necessary to every youth for sustainable empowerment. Unfortunately, majority of Nigeria's graduates do not 
have such skills relevant for them to be self-employed because of the poor implementation of entrepreneurship development programmes in their higher education institutions (Okolie, 2010).

In Nigeria, the customary academic education seems to have failed to meet the needs of a vastly increased school population; this incongruity become appallingly clear when one considers that over 70 percent of the gainfully employed persons require labor-intensive skills and technical knowledge (Okeke (2005); Odu (2010). At this stage in Nigerian development, a substantial section of the labour force must be able to initiate independent production or perform skilled work of a diversified nature. Skill acquisition is one of the surest ways through which graduates (youths) can find ways to the labour market either in the public or private sector. Ezeji and Okorie (1988) stated that the acquisition of mandatory skills is a means of increasing the industrious power of a nation, hence the Nigerian society should recognize the fact that every citizen should be well equipped to contribute effectively to the welfare of the country. According to Okeke (2005), the acquisition and development of these skills and knowledge is important so that the recipient would be able to cope with the complexities of the modern technological society especially now that the country's economy is indigenized.

Entrepreneurship education with skills and competencies acquired can help Nigeria maintain its material civilization by enabling the individual to keep pace with the rapidly changing business, industrial and technological growth and development. In other words, the future of entrepreneurship education must be seen as an instrument for transforming Nigeria's resources into finished goods and services that will promote higher standard of living (Olateju, (2013); Okolie, 2010).

\section{Entrepreneurship Education and Business Development}

The word Business can be defined as all profit directed towards economic and commercial activities that provide goods and services necessary to a nation's standard of living. Business is the monetary pulse of a nation because it serves to augment society's standard of living. Business development awareness, on the other hand is an act of developing ground-breaking strategies for earning livelihoods through establishing smallmedium and even large scale businesses. It also encompasses awareness of some fundamental functional scopes or areas in business development such as accounting, finance, information, systems, operations, market and management. According to Fawole, (2006), business can be viewed as a vocation which one engages in and does for a living. It is believed that all business must serve their customers in some way if they are to survive in the long run. Fawole (2006) further states that vocational business can be viewed as that education which leads to the acquisition of practical and theoretical skills on various vocations such as carpentry, carving, drafting, sewing, tailoring, welding, blacksmithing, knitting, barbing, weaving, vulcanizing etc.

In general terms, business development awareness is gotten through entrepreneurship education, which must focus on specific areas of occupations. Business development awareness should also be an integral part of the individual's total education, with programs related to trade and industrial occupations. As part of vocational education, it constitutes that part of education which prepares people for useful employment in reorganized occupations such as secretarial, accounting and administrative jobs and also be self-employed (Fawole, 2006). Individuals that are adequately trained in entrepreneurship education can be the pillars of the nation's economic growth and development in the nearest future, be gainfully employed in industries, be productive, and consequently contribute to the business and technological advancement of Nigeria.

Entrepreneurship education on the other hand, prepares young people to be accountable and innovative persons who become entrepreneurs' thinkers and contribute to development and sustainable communities. It provides opportunities for youths to be experienced, acquire entrepreneurial knowledge, skills, and attitudes including opportunity recognition, idea creation and marshalling resources in face of risk to chase opportunities, venture creation and operation, creativity and critical thinking. As noted by Mankinen and Turpeinen (1999), the purpose of entrepreneurship education is to support pupils knowledge, skills and attitude, of a kind he/she will need in his/her studies and later in the working life regardless of whether he'll be employed as private entrepreneur or hired by another person.

Entrepreneurial development studies if given the attention it deserves will help graduates and school leavers become self-reliant instead of depending on government or private sector jobs. Entrepreneurship development programmes facilitates expansion of human resources for self-employment by setting up small scale industries (Fasehun, 2013). The quality of performance of the entrepreneur determines whether capital would grow speedily or leisurely and whether the growth involves innovation where new products and production techniques are developed. The difference in economic growth rates of countries of the world is largely due to the quality of entrepreneurs in the countries. Production factors of land, labour and capital are said to be latent or indolent without the entrepreneur who organize them for productive ventures.

Entrepreneurship and entrepreneurship training has several definitions but for the purpose of this study, entrepreneurship is defined as the pursuit of opportunity regardless of resource currently controlled (Ashmore, 1989). In other words, it is the pursuit of opportunities beyond the resources one can control. An opportunity in this regard as noted by Banjoko (2013) is first identified, labour is put in, and consequently, fruits of one's labour are harvested. Entrepreneurship can be described as imaginative, creative and innovative response to the 
environment. Such response can take place in any area of human endeavor such as in building, woodwork, agriculture, education, social work and services of all types on the formation of small scale business unit within the informal sector.

According to Ashmore (1989), entrepreneurship is about growth, creativity and innovation and innovative entrepreneurs come in all shapes and forms. Achado (2004) stated that entrepreneurship is the process of creating something of value by devoting the necessary time and effort assuming the financial psychic and social risk and receiving the resulting rewards of monetary and personal satisfaction and independence. Olateju (2013), entrepreneurship training deals with the skills of business ownership and management. To Oyenuga (2005), it is the dynamic process of vision, change and creation and implementation of new ideas and creative solutions. Nwoye (2007) stated that entrepreneurship training refers to training and other support services incorporated within a structured programme designed to assist individual and group interested in becoming entrepreneurs and starting small business.

Effective entrepreneurship training programme in Nigerian higher education institutions will present many graduates lots of opportunities of starting small scale businesses while waiting to be employed in one's field of study. The entrepreneurship training must be focused on training students to gain skills even in areas outside their school curriculum for graduation in their respective departments. Baldwin (2002) argued that entrepreneurial skills students can acquire during training to enable them to be self-reliant include marketing skills, financial resources skills, self-motivation skills, time management skills, administrative skills, innovative skills, professional skills, practical skills etc.

\section{Statement of the Problem}

In recent years, the government, the parents as well as general public have expressed considerable anxiety over graduates' unemployment situations in Nigeria, though some blame it on the low performance of graduates of higher education institutions in the labour market; others stressed that many Nigerian graduates are not employable in the outside world (Oyenuga, 2005). They have little or no business development awareness and relevant skills to establish small scale businesses that'll enable them earn livelihoods. Therefore, the quest for self-reliance in trade, industrial and technological growth, and development boils down to the need for skilled personnel who will shrewdly utilize copious resources in Nigeria (Okolie 2014).

A man who has acquired useful skills in a particular trade should be able to help himself and at the same time be of assistance to others. He can help himself by making extra income for himself and living by it; at the same time, he can assist others by teaching them his acquired skills in the trade for a fee, thereby making more income for himself and his family. This means that skills acquisition is a means of providing oneself with opportunity for a acceptable livelihood. In the face of rising graduates' unemployment and the attendant youth restiveness, it is necessary that the tertiary institutions in Nigeria and other developing nations should be redirected towards achieving National and Global quest for reducing joblessness, poverty and youth restiveness through empowering them to become creative and productive citizens capable of establishing businesses and contributing to economic growth and development (Inclusive Growth).

\section{Purpose of the Study}

The general purpose of the study was to determine the influence of entrepreneurship education on students attaining business development awareness and skills acquisition in Nigeria. The study center of attention is on the students of the Nigerian higher education institutions. Specifically, the study;

1. Assessed the levels of business development awareness among tertiary institutions students created through teaching of entrepreneurship education.

2. Assessed the extent of tertiary institution students' skills acquisition through entrepreneurship education.

\section{Research Questions}

The following research question guided the study;

1. What is the level of business development awareness among tertiary institution students created through teaching of entrepreneurship education?

2. To what extent has the teaching of entrepreneurship education led to skill acquisition by the tertiary education students?

\section{Null Hypotheses}

The following null hypotheses were formulated and tested at 0.05 level of significance.

$\mathbf{H O}_{1}$ : There is no significance difference in the mean rating of male and female students on the level of business development awareness. 
$\mathbf{H O}_{2}$ : There is significant difference in the mean rating of male and female students on the extent of skill acquisition in entrepreneurship education.

\section{Methodology}

The design adopted for the study was an evolution design and the areas of study were Imo and Ebonyi States of Nigeria. A total population of five hundred and sixty (560) students was used. They were students drawn from five higher education institutions in the states offering entrepreneurship education as general studies (GST) courses. A purposive sampling technique was used in areas of study to select the schools and a simply random sampling technique was used to draw 56 students from each of the selected schools. 56 respondents were drawn because an objective test was used for the study and had to be marked to determine the extent. A sample size for the study was 280 respondents.

The instruments used for data collection was a multiple choice test question designed by the researchers. This was validated by three experts in entrepreneurial development studies department and entrepreneurship development centers of the institutions used for the study. After the item analysis, the instruments were subjected to test of internal consistency using the K-R 20- approach and a reliability coefficient of 0.96 was obtained. Therefore it was deemed reliable. The instrument was administered by hand with the help of six research assistants, three for each state. Data collected was analyzed using mean and standard deviation for each research questions. The decision to determine the extent of attainment was based on a criterion measure as indicated under determination of criterion of attainment. Mean for each section was calculated and compared with the cut-off scores for each section to determine the extern of attainment. The t-test statistics was used to test the two null hypotheses at 0.05 level of significance. The cut-off score for each of the two scores were;

Section A - 52 Business development awareness

Section B - 43 Skill acquisitions

The criterion for determining the level of attainment for each section were ranged in $21 \%$ internals to cover every score of the students as follows;

13-35 Very Little Extent (VLE)

35-56 Little Extent (LE)

57-78 Great Extent (GE)

79-100 Very Great Extent (VGE)

\section{Results/ Discussions} hypotheses.

The results of the data analysis are presented in tables below in line with the research questions and

Research Question 1: What is the level of business development awareness among tertiary institution students created through teaching of entrepreneurship education?

Table 1

Mean and Standard Deviation of the Level of Business Development Awareness among Students of Tertiary

\begin{tabular}{lcccc} 
Section A & \multicolumn{2}{c}{ Institutions in Nigeria. } & & \\
N & & Mean & SD & Decision \\
\hline Business development awareness & & & & \\
\hline Male & 142 & 45.95 & 14.80 & \\
Female & 132 & 43.14 & 16.91 & little extent \\
Total Population & 274 & 44.59 & 15.88 & \\
\hline
\end{tabular}

Based on the result on table 1, the mean achievement of the students on section A is 44.59 and this falls within the range of 35-56 indicating little extent of attainment in business development awareness. This was compared to the criterion of 52 obtained during the trail testing. Therefore, from the comparison it shows that the main achievement of the students on section A was found to be lower that the criterion, indicating that the students have little extent attainment of business development awareness. This is in line with what Okolie (2014) found in his study, that what is seen today is that skills training in Nigerian higher education institutions with goal on training people to be employed in commerce and industry or any enterprise using tools and machinery for operation, production, construction and distribution of goods and services has been too theoretical which has not placed much emphasis on the trainees' practical skill acquisition.

Instructors in most cases, use unsuitable delivery methods such as, lecture method and deductive/ inductive method as subject delivery for training learners for the world of work. According to Arubayi, Nworgu, 
Akpochafor, and Odu (2009), appropriate delivery methods should be emphasized in skill training. Such methods include: demonstration, real life applications, concept formation, job related skills acquired by trainee, diagrams /illustrations/ drawings. Also, it has as well been discovered that entrepreneurship education teachers who should facilitate business development awareness often teach the students theoretical aspects due to lack of instructional materials and equipment and where equipment are available in some institutions' workshops, they are often obsolete (Okolie, 2014).

Research Question 2: To what extent has the teaching of entrepreneurship education led to skill acquisition by the tertiary education students?

Table 2

Means and standard Deviation of the Students' level of Skill Acquisition from the teaching of entrepreneurship education

\begin{tabular}{lllll} 
Section B & N & Mean & SD & Decision \\
\hline Skills Acquisition & & & & \\
\hline Male & 142 & 40.88 & 18.96 & \\
Female & 132 & 37.40 & 20.50 & little extent \\
Total Population & 274 & 39.20 & 19.76 & \\
\hline
\end{tabular}

Based on the result on table 2, the mean achievement of the students on the extent of skill acquisitions from the teaching of entrepreneurship education is 39.20 and this falls within the range of 30-56 indicating little extent of attainment of skills acquisition. Also the mean 39.20 when compared to the criterion of 43 obtained during trial testing indicates that the mean achievement of students on section B is lower than the criterion. Therefore, students have achieved little extent on skills acquisition through teaching of entrepreneurship education in their institutions. This in line with the words of Okolie (2010) that the purpose of entrepreneurship education is to support pupils' knowledge, skills and attitude, of a kind he/she will need in his/her studies and later in the working life regardless of whether he'll be employed as private entrepreneur or hired by another person or public sector. Entrepreneurship is a dynamic process of vision, change and creation; it requires an application of energy and passion towards the creation and implementation of new ideas and creative solutions. It bridges the gap between science, technology and market (Udu, Udu and Eze, 2008). In line with the words of Dollinger (2006) entrepreneurial development studies prepare young people to develop skills that enables them survive, earn livelihoods, be responsible and enterprising individuals who become entrepreneurs' thinkers and contribute to development and sustainable communities.

According to Okolie (2010), every higher education institution in Nigeria should be encouraged to give entrepreneurship training the attention it deserves as it assists students develop attitudes of translating their visions into economic and commercial activities, make them part of the development processes in their various communities, helps to channel the strengths of many idle graduates into being productive citizens and make positive changes towards economy improvement; hence more graduates will be involved in producing locally made goods and services they'll be able to sale to make money in exchange. Also, According to Evans (1971), skills acquisition yields sociological, psychological and economic contentment. Skills acquisition leads to a rise in per capita income of a nation. This is because everybody will be involved in independent production of goods which will lead to increase in the country's foreign exchange. As a result of the increase in foreign exchange due to skills acquisition, there will be a rise in the standard of living of the people. This rise in the standard of living of the society will be particularly welcomed especially in the developing countries of which Nigeria is one (Odu, 2010). Skills acquisition brings extra-economic benefits like national prestige and self-sufficiency in certain critical products like fire arms. From the point of view of the aims of the national policy, these extraeconomic benefits like manufacture of fire arms are no less important than the purely economic ones such as independent production o goods and services, which are the purely economic ones and the extra-economic whatever.

Table 3:

T-test Analysis Mean Ratings of Male and Female Students on the Level of Business Development Awareness through entrepreneurship education.

\begin{tabular}{lllllllll}
\hline Variables & $\mathrm{N}$ & Mean & SD & SE & t-cal & Alpha & t-value & interference \\
\hline Male & 142 & 45.95 & 14.80 & & & & & \\
Female & 132 & 43.14 & 16.91 & 1.92 & 1.46 & 0.05 & 1.96 & Upheld \\
\hline
\end{tabular}


The result in the table 3: shows that t-cal is 1.46 and this less than t-value of 1.96 at 0.05 of significance. This implies that there is no significant difference between mean ratings of male and female students on the level of business development awareness. Therefore, the null hypothesis $\left(\mathrm{H}_{1}\right)$ was upheld at 0.05 level of significance.

Table 4:

T-test Analysis Mean Ratings of Male and Female Students on the extent of Skill Acquisition from teaching of entrepreneurship education

\begin{tabular}{lllllllll}
\hline Variables & $\mathrm{N}$ & Mean & $\mathrm{SD}$ & $\mathrm{SE}$ & $\mathrm{t}$-cal & Alpha & $\mathrm{t}$-value & interference \\
\hline Male & 142 & 40.88 & 18.96 & & & & & \\
Female & 132 & 37.40 & 20.50 & 2.39 & 1.46 & 0.05 & 1.96 & Upheld \\
\hline
\end{tabular}

The result in table 4 shows that $t$-cal is 1.46 and this is less than t-value of .1 .96 at 0.05 level of significance, this therefore implies that there is no significant difference in the mean ratings of male and female students on the extent of skill acquisition through teaching of entrepreneurship education. Therefore, the null hypothesis $\left(\mathrm{HO}_{2}\right)$ was upheld at 0.05 level of significance.

\section{Findings}

Based on results of data analyzed in tables 1-4, the following key findings were made;

1. Students have attained business development awareness to little extent as a result of entrepreneurship education in their various institutions. Based on this, entrepreneurship education, which must be practical oriented, should be encouraged and funded by the government of Nigeria as this will assist in nation's building in the nearest future.

2. Entrepreneurship education has made higher institution's students acquire business, technical, managerial and marketing skills to little extent.

3. Business development awareness of both male and female students was on the same level because there was no significant difference on their mean ratings from the t-test analysis made.

4. The performance of male and female students on skill acquisition through the teaching of entrepreneurship education is same in their mean ratios from the t-test analysis made.

\section{Conclusion}

We revealed in this study how entrepreneurship education in higher institutions in Nigeria has created diminutive impact on students' attainment of business development awareness and skill acquisition. Entrepreneurship education have not used to achieve reduce youth unemployment in Nigeria since the students graduate with little or no practical knowledge on how to develop his business This indicates that efforts should be made by the federal and state governments to improve the study of entrepreneurship education, which must practical oriented in Nigerian tertiary Institutions. The study concludes by suggesting that using appropriate teaching strategies for proper skill acquisition, among others will create workable options and facilitate graduates acquire skills to be entrepreneurs, capable of contributing to the growth and development of the nation. It is now time we suggest to make entrepreneurship education more practical oriented instead of theories, which we see in many of our higher education.

\section{References}

[1]. Achado, Y. A. (2004). MBA Project. Development of Private Entrepreneurship in Nigeria: Case Study of Benue State. 17-25.

[2]. Ashmore, M., C. (1989). The Power of Entrepreneurship Vision. Vocational Education Journal. (64) 186.

[3]. Akpojena, E., P. (2010). Skills Acquisition in Nigerian Educational System Problem and Prospects: Experience of a Textile Designer. Journal of Qualitative Education, 6 (1) 70-76.

[4]. Baldwin, F. D. (2002). Teaching Entrepreneurship Skills to Youth. Journal of Business Venturing 16 (2), 345-355. Columbia Enclopedia ( $6^{\text {th }}$ Education). Colombia University press.

[5]. Banjoko, M., O. (2013). Incorporating Entrepreneurship Education into Building Technology Education Curriculum in Technical Colleges in a Developing Economy. Technology Education Journal. 9 (1) 27-33

[6]. Dollinger, M. J. (2006). Entrepreneurship, Strategies and Resources. Delhi. Pearson Education.

[7]. Ezeji, S., C., O., A. and Okorie, J., U. (1988). Elements of Guidance, Vocational and Career Education. Summer Educational Publishers.

[8]. Fasehun, O. O. (2013). Technical Manpower and Entrepreneurship in a Developing Economy. Technology Education Journal. 9 (1). PP 34-39.

[9]. Fawole, J.O. (2006). Education Challenges of the $21^{\text {st }}$ Century. Ebonyi State University Journal of Education. 4 (1).3-7

[10]. Gutheri (1952): http://www.exrx.net/psycology skill.html.

[11]. Federal Republic of Nigeria (2004). National Policy on Education (4 ed.) Lagos: NERDC Press.

[12]. Hull, H.S. (1982). Method and Problems in Apprenticeship System. New York. The Century Publishing. Co. 
[13]. Mainkinen P. and Turpeinen, J. (1999). Entrepreneurship and Technology Education. Finish Initiatives. Cough-borough University. 146-150.

[14]. Njoku, H. (2002): Alleviation of Poverty the Inculcation of Home Economics, Based Life (survival) Skill in Rural Women in Nigeria in E.U. Anyakoha (ED) (2002). Journal of Research Issues in Home Economics, 172-178.

[15]. Nwaham, C., O. (2010). Skill Acquisition and Teacher Education: Problems and Prospects. Journal of Qualitative Education, 6 (1) $58-62$.

[16]. Nwoye, M. (2007). Gender Responsive Entrepreneurial Economy of Nigeria: Enabling Women in a Disabling Environment. http//www.mamma.com. Retrieved $27^{\text {th }}$ November, 2013.

[17]. Nwuzo, A. C., Okolie, U., U., and Igwe, E., N. (2013). Promoting Girl-child Education: Model for Achieving Gender Equality and Women Empowerment in Nigeria. Women in Colleges of Education Research Journal. Maiden Edition. 349-366.

[18]. Odu, O., K. (2010). Skills Acquisition in Nigerian Education System: Problems and Prospects in Technical Education. Journal of Qualitative Education, 6 (1) 20-26.

[19]. Olateju, E., O. (2013) Towards an Effective Entrepreneurship Training in Technical and Vocational Education and Training in a Developing Economy. Technology Education Journal. 9 (1) 98-100

[20]. Okeke, E.C. (2005). Instructional Materials for Environmental Adult Education: Challenges for Curriculum Development in Nigeria. Journal of Curriculum Organization of Nigeria, 12 (1), 288-291.

[21]. Okeke, C.A. (2005): Improving Student's Skill Acquisition through Effective Clothing and Textiles Education in Tertiary Institution in Anambra State. Journal of Home Economics Research (1) 85-89.

[22]. Okolie U. C. (2014), Management of Woodwork Workshop in Tertiary Institutions in Nigeria: An Analytical Study. Malaysian Online Journal of Education. 2 (1) 20-36.

[23]. Okolie, U. C. Entrepreneurial Development Studies in FUNAI; the Missing Links. An unpublished proposal submitted to the University on Entrepreneurship Education.

[24]. Okolie, U. C. (2010),: Entrepreneurship Development through Technical and Vocational Education for Self-employment and Youth Development in African. International Journal of Learning. 17 (5). 577-578.

[25]. Okorie, J., U. (2000): Development Nigeria's Workforce. Calabar, Macaky Environs.

[26]. Onyeachu, J.A.E (2006). Management of Primary Education in Nigeria. Journal of Curriculum Organization of Nigeria. 13 (3), 191 201.

[27]. Osuala, E.C. (1995): Foundations of Vocational Education, Nsukka: Fulladu publishing company.

[28]. Oyenuga, B., A. (2005). Vocational and Technical Education for Self-sustenance among Nigerian Youths. Paper Presented at the $18^{\text {th }}$ Annual National Conference of Nigeria Association of Teachers of Technology. Rivers. Nigeria.

[29]. Uloko, M., E. (2010). Skill Acquisition in Nigeria Educational System through Home Economics Education. Journal of Qualitative Education, 6 (1). 20-26. 